\title{
Pobreza e Humanismo Salvador: Mediações Subjacentes
}

\author{
Delma Pessanha Neves
}

$\square$ reconhecimento dos extremados índices de desigualdades socioeconômicas na sociedade brasileira funda-se, recorrentemente, nas diferenças quanto ao acesso à renda e à precária qualidade dos serviços sociais básicos oferecidos aos segmentos da população que deles dependem. Contudo, a diferenciação socioeconômica intensifica-se pela segmentação de universos de cognição e pela produção de barreiras de comunicação interpessoal e institucional entre os diversos e hierarquizados segmentos populacionais. Os que estão integrados sob precariedades materiais, por isso mesmo, também o estão por suspeitas de produção de riscos sociais e de fragilidades morais.

Como recurso compensatório da exacerbada segmentação social, que se convencionou denunciar como exclusão social ${ }^{1}$, o voluntariado filantrópico tem se expandido e se consagrado, não só pela transferência de recursos materiais, mas principalmente pela criação controlada de canais de comunicação e de redimensionamento social dos pobres por eles selecionados ou projetados como bem-aventurados ${ }^{2}$.

As concepções filantrópicas que qualificam os termos pobres e pobreza, associadas ao relativo voluntarismo orientado, assumido pelos fiéis que aderem aos procedimentos de objetivação de sistemas de crenças cristãs, são elaboradas em consonância com a definição de modos de gestão social das acentuadas desigualdades socioeconômicas. Consti-

DADOS - Revista de Ciências Sociais, Rio de Janeiro, Vol. 50, n-1, 2007, pp. 117 a 158. 
tuem-se, assim, mediante significações que caricaturam as polarizadas posições denunciadas: pobres e ricos ${ }^{3}$. Elas representam um patrimônio cultural da humanidade ocidental e fundam um celeiro ideológico para constituição de textos (orais ou escritos) de projetos políticos, que registram as formas de ordenação social vislumbradas. O maior ou menor reconhecimento e a legitimidade desses projetos caminham na ordem inversa à constituição ou à expansão das práticas estatais concorrentes, isto é, também destinadas à reconstrução da ordem social. Circunscrevem-se, entretanto, aos fenômenos de expressão de desigualdades socioeconômicas que não coloquem em xeque a ordem pública.

A presença de instituições filantrópicas responde ao aparecimento, à ampliação ou ao reconhecimento político da miséria popular. A exposição das mazelas sociais pelos pobres, em contraposição, suscita o aparecimento de idéias populistas ou reformadoras e de instituições caritativas. Estas próprias instituições estimulam a expressividade da miséria e a migração daqueles que devem sobreviver sem as alternativas complementares aos baixos, esporádicos ou inexistentes salários. Concentradas nas grandes cidades, suas presenças assim configuradas colaboram para a visibilidade dos pobres, porque os tornam mais expostos $^{4}$.

As instituições filantrópicas vêm ainda encontrando expressiva expansão no contexto de produção de debates sobre a constituição de novas referências para criação de formas de solidariedade entre os socioeconomicamente desiguais. A expansão ancora-se no recrutamento de ações organizadas em torno de associações mantidas e reproduzidas pela utopia voluntarista, utopia legitimada pela ideologia da solidariedade, pelo militantismo cristão e pela reivindicação de uma humanidade única, universalizada em Cristo.

Além disso, e concomitantemente, a prática assistencialista estatal tem se orientado pela constituição de parcerias ou de alianças políticas com instituições filantrópicas, sob o argumento da conquista da governança $^{5}$. As alianças e os compromissos fundamentam-se na capacidade mobilizadora dos titulares dos sistemas institucionais de crenças religiosas, razão pela qual eles são estimulados a confluírem para o reconhecimento de sistemas de trocas e adesões.

A despeito de o processo de constituição de instituições filantrópicas acompanhar os de urbanização, sendo boa parte delas anterior à década de 1980, momento de recrudescimento da visibilidade e reconheci- 
mento de pobres publicamente expostos sob condições de vida miseráveis, muitas delas foram reordenadas e revitalizadas nesse contexto, e outras tantas emergiram sob o ideário político da associação entre cidadania e solidariedade. Diversas campanhas sociais vêm sendo concertadas para a produção de versões mobilizadoras, agregando assim cidadãos comuns e representantes de organizações das mais diversas ordens. Muitas dessas ações objetivaram-se em sintonia com (e a partir de) mobilizações políticas encetadas diante da calamidade oficialmente reconhecida pelo Mapa da Fome, elaborado pelo Instituto de Pesquisa Econômica Aplicada - IPEA da Secretaria de Planejamento do governo federal. Por este mapa, elaborado e divulgado em 1993, foram contabilizados 32 milhões de pessoas vivendo em situação de indigência no país.

A fome, reconhecida massiva por efeitos das campanhas, vem sendo provisória ou pontualmente saciada. Inúmeros cidadãos, nesses termos caracterizados como não-famintos, demonstraram a disposição para se engajar em "campanha disposta a resgatar a solidariedade como ato humano e político e não apenas a desenvolver ações de caráter emergencial" (Jacobi, 1995:28). A solidariedade, as ações em parceria e a descentralização impuseram-se como referências para ação pública; ou como temáticas mobilizadoras do engajamento dos reais ou potenciais doadores ou redistribuidores de bens e serviços. Os políticos, nos planos legislativo e executivo, tiveram que incorporar, por vezes só nos textos discursivos, propostas similares, embora muitos deles dissimulassem as ações caritativas ou tentassem diferenciar os modos de transferência de bens. Celebrou-se o combate à fome, como demonstra o sucesso das transferências de produtos não-perecíveis, mas não à pobreza, mesmo aquela que se apresentava como miserável e, posteriormente, como justificativa para objetivação de programas de redistribuição de renda, sob rótulo Fome Zero.

Como se pode concluir, as formas de participação dos agentes no campo institucional do voluntariado filantrópico são extremamente dinâmicas, acompanhando a diversidade de percepções e a engenhosidade de soluções paliativas para a pobreza intolerável ou assustadora. No atual contexto, os modos de constituição deste campo de mediação de empreendimentos redistributivos, postos em prática para comunicação e provisão da convergência de interesses entre benfeitores e beneficiários, são devedores das condições em que se complementam e se contrapõem as práticas da caridade estatal e voluntária. 
Independentemente da diversidade, os significados atribuídos à carida$\mathrm{de}^{6}$, em plano geral concebida como atos de entrega ou doação de si (tempo, sentimentos, atenção) mediante ou não transferência de bens materiais, estruturam uma relação de troca fundada na desigualdade de acesso a recursos de dimensões múltiplas. Apresentam-se como uma referência para comportamentos, diante do reconhecimento de que os homens, mesmo que sua prática vise negar o que moralmente possa ser abominável, estão organizados sob extrema desigualdade. Eles sinalizam, assim, a construção de princípios estruturantes de um sistema de posições relacionais. Eles suscitam a construção de discursos sobre os benfeitores ou benévolos, especialmente aqueles que são providos de meios de verbalização da imagem autoconstruída sobre a posição ocupada; ou que desejam tê-la legitimamente reconhecida, a ponto de, em nome da filantropia ou do amor à humanidade, propor projetos coletivos de redimensão dos homens e, com isso, da sociedade.

A partir de tais significados, vêm sendo explicitadas as alianças e os confrontos sustentados nas potencialidades acumuladas por agentes estatais e filantropos, hetero- ou auto-outorgados à construção e ao enfrentamento das questões sociais vinculadas à pobreza sob miserabilidade.

\section{O ENCONTRO ENTRE CARENTES, FILANTROPOS E ABASTADOS}

Para analisar alguns dos modos de objetivação de projetos políticos anteriormente aventados, proponho-me, neste artigo, a examinar as condições de constituição de um campo de negociação e intervenção, articulado pela crença no humanismo salvador. De um lado, os voluntários filantrópicos, que recriam condições de comunicação e circulação de bens entre pobres. De outro, os que reivindicam a condição de necessitados ou carentes e galgam este reconhecimento mediante cadastramento institucional, que formaliza a posição estabilizável do beneficiário. Dessas posições relacionais, mobilizam-se os abastados, isto é, os que se pensam em condições e obrigações da transferência de bens e de reafirmação da irmandade em Cristo. Este espaço de intercomunicação, constituído por relações tecidas em alegadas situações limítrofes de fronteiras culturais e de encontro de desiguais (no sentido socioeconômico), configura-se como um campo de mediação. Como nas interações que no campo ganham sentidos reafirmam-se teatralmente as diferenças, sua análise pode revelar os termos de gestão desta comunicação provisória e espacializada. Constituída por interesses diversos e 
até divergentes, a intercomunicação ancora-se na produção de sentidos que aí entram em concerto relativo. Ela, por conseguinte, não se limita ao contato imediato, mas se constitui a partir da adoção comum de certos termos e categorias, cujos significados nesse campo são partilhados ou construídos para esta partilha. As trocas comunicativas estabelecidas pela adoção de termos comuns permitem o trânsito e o encontro específico de universos diferenciados de significação.

Correntemente, o termo mediação tem sido interpretado de forma essencialista, enquanto ponto de união do diverso e não-correspondente, perdendo o seu caráter processualista e dialético para ressaltar aspectos sistêmicos ou até mecanicistas. Por esta perspectiva, o termo alude à conciliação diante de divergências ou da intervenção de outrem com o objetivo de propor o acordo ou o compromisso. Faz ressaltar a objetivação de sistemas de regulação instituídos para reduzir a dissonância entre visões de mundo e formas de comportamento de distintos segmentos constitutivos das sociedades complexas. Equivale à institucionalização de um sistema de regras destinadas a assegurar a hegemonia de uma ordem consagrada ou em busca de consagração. Contempla fenômenos cuja objetividade põe em jogo relações sociais estruturadas por interações ou interseções, ou que agregam redes que se intercruzam ou se confundem.

Sob uma perspectiva analítica processualista, o termo mediação pode aludir a engajamentos e à mobilização de segmentos selecionados para reordenação de modos de conduta e de visão de sua posição social. Contempla os modos de constituição e objetivação de um conjunto de princípios-guias para as interpretações que tornem possível a comunicação intencionada, interessada, por isso, negociada entre agentes vinculados a universos de significados diversos e divergentes. Instaura um patrimônio comum para esta comunicação, constituindo os laços que permitem relativizar as propriedades sociais de cada agente que, por contraposição, aí acede. Opera como espaço de institucionalização do que pode ser partilhado, de modo a permitir a interação pelo debate ou o diálogo em torno de temas comuns que propiciem a experiência de interseção ${ }^{7}$.

Tanto no caso da reordenação ou afirmação de determinados modos de integração, como nos contextos de questionamento da ordem instituída, os investimentos para a interseção de agentes - dotados de interesses divergentes e visões de mundo por vezes contraditórias - só alcan- 
çam resultado pela negociação dos meios de concorrência ou de disputa. Portanto, nessas circunstâncias, campos de mediação devem ser constituídos para permitir o trânsito entre fronteiras de universos sociais, assim concebidos por explicitarem a interseção e não a homogeneização.

Neste texto, valorizo os atos de mediação cultural orientados pela produção de adesão ou de consentimento (mesmo que provisório e pontual) entre benfeitores e beneficiários afiliados à Sociedade Espírita Fraternidade (doravante SEF). Esta, entre outras instituições participantes do campo da filantropia que foram por mim pesquisadas, está sediada na cidade de Niterói, Estado do Rio de Janeiro ${ }^{8}$. Nesta instituição, observou-se diretamente a interação entre os patronos voluntários e os clientes beneficiários, situação na qual eram explicitados pontos de vista e construídas imagens e representações recíprocas 9 .

Formalmente ou aparentemente, as relações em jogo no campo organizado por trocas caritativas orientam-se pelo respeito recíproco entre doadores e receptores, pela deferência e pela obediência comum a preceitos. No entanto, o consentimento, neste campo de fato constitutivo da representação da posição dominada, apresenta-se como um investimento do qual o subordinado espera a obtenção de bens ou o atendimento de interesses próprios. As respostas encenadas, mesmo que orientadas por relações paternalistas, não podem ser entendidas pela passividade. Há um jogo exercido sob clivagens próprias; há cumplicidades assumidas entre os que comandam e os comandados; há articulação de relações de vizinhança e parentesco, impostas pelos dependentes; há recursos de dramatização ostentados nas situações de desqualificação da dominação ou do dominante, denunciando comportamentos inadequados, atitudes inesperadas, posturas desviantes, qualificadas como antiéticas.

Por isso mesmo, na análise do campo de mediação para instaurar a comunicação e a redistribuição entre filantropos e carentes, levo em conta a definição que estes dois agentes dão de si mesmos e da situação que desejam projetar, reproduzir ou reordenar. Invisto atenção especial sobre o que eles revelam e ocultam, mas também como eles concebem os modos mais adequados de funcionamento das relações institucionais (cf. Moore Jr., 1987; Weber, 1977).

A diversidade de pontos de vista e interesses dos diferentes agentes que constituem o campo de mediação, ou que ocupam as posições cen- 
trais (voluntários filantrópicos e demandantes de ajuda ou pedintes), deriva não só dessa polaridade situacional aí assumida: benfeitor abastado e beneficiário carente. Ela também está sustentada nas diferentes formas de concepção dos direitos humanos à sobrevivência e à luta por reconhecimentos sociais, embora sejam fatores que possibilitam aos beneficiários uma participação mais significativa e até reversiva quanto às concepções e às regras que aí são hegemônicas. Por isso, na análise, considero os diferentes e coexistentes campos de ação e de significação que aí se imbricam, a agregação mediada de redes de relações e, por conseqüência, os modos contrapostos de institucionalização de regras para redistribuição de recursos. As regras e os recursos respondem, sob certa plausibilidade, a estes interesses distintos e divergentes dos representantes das diversas posições aí assumidas. No decorrer do exercício de redistribuição de recursos, tanto há a reafirmação de regras e princípios construídos para nortear a relação, provisória e contextualmente celebrada, como também são constantemente redefinidas as condições de construção de diferentes referências identitárias ${ }^{10}$.

Contrapondo alternativas constituídas pela participação em redes de instituições concorrentes e de amizades, estas mesmas criadas para que os usuários possam se integrar ao campo institucional da filantropia, tais agentes tentam conquistar certa autonomia. Esta autonomia é importante para tomada de decisões sem o aval dos tutelares benfeitores e para compensar a instabilidade e a inventividade adaptativa que caracterizam a estruturação das instituições em foco. A autonomia é de fato relativa porque só se torna possível se os usuários forem capazes de garantir a afiliação a outras instituições destinadas à redistribuição filantrópica. As diversas afiliações propiciam a obtenção de recursos materiais e imateriais que consideram básicos, mas eles também canalizam os resultados para atender a formas de apropriação pretendidas.

A análise das relações dinâmicas que ocorrem entre os diversos agentes que participam do campo institucional organizado pelo voluntariado filantrópico não pode, por conseguinte, perder de vista a dimensão da provisoriedade. Esta provisoriedade é sistematicamente organizada no tempo, exatamente para reafirmar a perspectiva temporal da adesão e os riscos da descontinuidade da relação ${ }^{11}$.

$\mathrm{Na}$ concorrência organizada a partir desses diferenciados projetos de ordenação social, há investimentos para distinguir as lógicas das ações da prática caritativa estatal e as da filantropia destas próprias ações em 
contraposição às destinadas a implementar a seguridade social. Contudo, os projetos têm sido associados e complementados segundo a ideologia das ações em parceria (ver Neves, 2002a). Os recursos que vêm se tornando disponíveis pela prática de redistribuição originária do Estado brasileiro, diante do reconhecimento do problema social articulado à insegurança alimentar, têm se assemelhado aos postos em circulação pelos representantes de instituições filantrópicas. Ambos projetos são elaborados para integrar ações destinadas à redistribuição seletiva e pontual de recursos equivalentes a cestas básicas, ora computadas por produtos alimentícios não-perecíveis ou, mais recentemente, por valor correspondente em crédito ou dinheiro imediato. Nesse caso, a oferta de bens mínimos tem sido então dissimulada (bolsa-escola, cheque-cidadão, bolsa-família etc.), dada a própria concorrência quanto à inventividade da solução ou à descaracterização da ação assistencial e paliativa ${ }^{12}$. A ação estatal diferencia-se, contudo, pela reivindicada outorga de instância coordenadora e estimuladora dos valores norteadores da integração solidária e das associações comunitárias.

Os recursos financeiros estatais transferidos como auxílio continuado a indivíduos considerados improdutivos (do ponto de vista médico: velhos, deficientes físicos e mentais) têm demonstrado sua eficácia pela reordenação dos papéis desses familiares incapacitados para o trabalho. O exemplo mais abrangente é o das avós, como demonstram várias pesquisas voltadas para as condições de reprodução física e social da população que sobrevive mediante deficiência de recursos materiais ${ }^{13}$. Contudo, tais medidas ainda têm contemplado uma pequena fração da população que sobrevive sob a ajuda de terceiros, ou que conseguiu ter acesso à previdência ou aos benefícios prescritos pela Lei de Assistência Social - Loas (1993) ${ }^{14}$.

A convergência quanto aos valores ideológicos que constroem a legitimidade da redistribuição assistencial patenteia a forma como a precariedade de vida da massa da população empobrecida tem sido considerada. Os programas são assistenciais e emergenciais, posto que as decisões quanto à redistribuição são periodicamente revistas e suspensas, se a renda per capita individual na família ultrapassar um quarto do valor do salário mínimo. Eles, outrossim, fundamentam-se em valores humanísticos que referenciam a solidariedade social. A noção de cidadania que comumente informa e dissimula tais práticas de definição de pertencimentos, mas assegura a participação de indivíduos assim 
reordenados para integrar o campo da filantropia, prescinde das ações implementadas por agentes do Estado. Por ela também são revitalizadas as associações privadas e voluntárias. A noção abrange a reclassificação dos benfeitores, atores das práticas solidárias de atendimento emergencial, e seus pobres, os beneficiários.

\section{SOCIEDADE ESPÍRITA FRATERNIDADE}

ASEF foi fundada em 4 de setembro de 1980, a partir do projeto de um grupo de 14 associados da Federação Espírita do Estado do Rio de Janeiro - Feerj, visando objetivar uma proposta autônoma de intervenção na sociedade, mediante a elaboração e o reconhecimento de um problema social digno de controle e prevenção. Segundo registros de memória preservada pelos seus fundadores, eles decidiram entregar-se à assistência a crianças faveladas e seus familiares, e o fizeram obedecendo à enunciação de um espírito que vaticinara a um dos médiuns a sua missão, para a qual contaria com outros - companheiros - integrantes do sistema de crenças, todos destinados a realizar tal projeto de melhoria das condições de vida material e moral de crianças pertencentes a famílias empobrecidas.

O projeto de intervenção social configurou-se por um sistema de crenças e atitudes orientado pelo espiritismo, visão de mundo codificada por Allan Kardec, que nega o reconhecimento de uma única dimensão da vida na sociedade, qualificada como materialista. Os seus elaboradores e seguidores vêm se consagrando a construir o reconhecimento de uma visão de mundo que preconiza vida além do corpo físico e social. A definição, entretanto, comporta outras segmentações, como a diferenciação do espiritualismo - variação da crença na reencarnação ritualizada nas práticas identificadas como (ou nesse caso acusadas de) umbandistas. Os seguidores deste sistema de interpretação da vida humana também colocam em prática trabalhos paralelos de assistência social e material. A importante diferenciação social, em um primeiro plano, coloca em distinção a reivindicação de uma fé raciocinada ou refletida, princípio pelo qual a diretoria institucional valoriza a formação, o estudo, a auto-reflexão dos fiéis.

No contexto da enunciação daquela missão, eram menos constritas as trocas hierarquizadas e as formas de sociabilidade que agregavam segmentos da classe média identificados à posição de benfeitores e aqueles diferenciados como pobres ou beneficiados, por residirem em favela. 
Os fundadores da SEF, respaldados pelo pertencimento a grupos doutrinários da Feerj, iniciaram seu trabalho, ainda sem objetivação física da instituição, nos lares dos moradores da Favela do Gás, em Niterói (RJ). Dado o recrudescimento da violência decorrente de disputas entre rivais comerciantes de drogas e destes com policiais, o trabalho de evangelização in loco foi interrompido. Os beneficiários foram então convidados a freqüentar as dependências físicas das sucessivas edificações da sede da SEF.

Este desdobramento indica mudanças nos padrões relacionais de inserção das camadas da população que sobrevivem com escassos recursos materiais. Para algumas famílias, o isolamento social produzido pelas condições de relacionamento interclasses tem se ampliado, com a interrupção de visitas domiciliares diante do recrudescimento das disputas nos aglomerados populacionais qualificados como favelas. Para outras, este mesmo isolamento atuou na mobilização de estratégias para formulação de demandas junto aos dirigentes das instituições. Os dirigentes, por seu lado, também investiram no sentido de minimizar o desconhecimento ou aplacar os efeitos das visões preconceituosas, construídas por posições cada vez mais externalizadas diante de um mundo social de regras próprias. O caso também indica mudanças nas formas de dominação que orientam as práticas filantrópicas, minimizando o caráter mais pessoal e ampliando o formal das práticas institucionais.

A SEF (no contexto do trabalho de campo: outubro de 1997 a março de 1998) contava com mais de 200 sócios, diferenciados em: a) fundadores, na ocasião apenas quatro, responsáveis pela elaboração e reprodução da doutrina e dos princípios orientadores dos serviços prestados e da reprodução da instituição; b) mantenedores, encarregados da reprodução simbólica e material do empreendimento social, através de contribuições financeiras e prestação de serviços como voluntários; c) contribuintes, voluntários na transferência de recursos financeiros ou materiais, mas sem responsabilidade quanto às condições de aplicação da proposição institucional. Os sócios fundadores e mantenedores eram elegíveis e elegiam o conselho administrativo e a diretoria, conforme política de sociabilidade e governabilidade constituída pelos participantes; mas também segundo a legislação pertinente ao reconhecimento oficial deste tipo de instituição. Todos eram trabalhadores da casa, incluídos mediante papel na divisão social das atividades internas à instituição. 
A composição social dos participantes diferenciadamente posicionados podia, grosso modo, ser caracterizada como originária de segmentos de classe média, especialmente de categorias profissionais mais intelectualizadas. Destacava-se a presença de professores e alunos de universidades, condição que permitia a instituição diferenciar também a assistência social prestada, não só em termos materiais, mas em serviços especializados.

A elaboração do projeto de intervenção social pressupõe a constituição de condições de visibilidade pública, expressas na contínua expansão e na edificação de sedes institucionais, cuja magnitude ou simplicidade são reveladoras do sucesso ou dos constrangimentos enfrentados na objetivação de tal proposta. Por isso, na construção da memória da trajetória do projeto e do grupo que o implementa, é valorizada a referência à construção da sede própria e à contínua elaboração de projetos de segmentação e expansão dos serviços, acompanhadas de edificações de subsedes. O alcance de tais intenções é dependente dos efeitos práticos da mobilização e conquista de adesões ou sócios. Estes se engajam na transferência de recursos financeiros, sob a forma de doações ou prestação de serviços, e na conquista do reconhecimento social da importância da missão.

ASEF integra um complexo institucional que abarca uma sede própria, em São Domingos, e uma subsede, Colônia Remanso Fraterno, em Várzea das Moças, bairros de Niterói. Com esta infra-estrutura, o corpo de sócios atendia em média, no contexto do trabalho de campo, 115 crianças e 150 adultos. A sede está situada em edifício de três andares, com salas para evangelização e salão para palestras e preces, secretaria, biblioteca e cozinha, bem equipados em termos de mobiliário. A estrutura imobiliária da Colônia encontrava-se em construção no momento do trabalho de campo, já tendo sido erguidos os espaços correspondentes ao serviço administrativo, ao posto médico e ao serviço educacional. Um conjunto composto por cozinha, refeitório e armazém estava em fase de finalização.

Pelo projeto em si, a diretoria da instituição reconhecia as deficiências de órgãos do Estado na oferta de serviços sociais a segmentos da população que não contam com rendimento financeiro para remunerá-los se oferecidos por empresas privadas. Portanto, como tantas outras instituições assistenciais ou filantrópicas, a SEF vem sendo organizada para concorrer e complementar serviços anteriormente atribuídos a 
instituições públicas, criadas e referenciadas pelo, entre nós inalcançado, ideário de objetivação do Estado de Bem-Estar.

Os serviços prestados na SEF eram organizados por departamentos cuja identificação expressava o leque dos recursos materiais e imateriais transferidos e trocados: possui departamento de doutrina e evangelização, assistencial, de obras, editorial, de divulgação, da infância e da mocidade. A distribuição dos departamentos era reveladora da divisão de trabalho e de responsabilidades. A administração da sociedade estava pautada na redistribuição de decisões por colegiados. Os múltiplos serviços eram concatenados por coordenadores.

Como recurso que tornasse viável a evangelização das crianças e adolescentes, os dirigentes da SEF ampliaram as linhas de ação, oferecendo meios de mobilização e engajamento dos pais, alternativa também estendida para outros interessados. Aos domingos, dia dos carentes, todos participavam de sessões pedagógicas, orientando os usuários quanto à construção de novas percepções sobre o mundo e sobre si mesmos. O projeto pedagógico também se sustentava na oferta de bens materiais, como almoço e algumas cestas básicas, roupas, calçados e medicamentos.

O almoço, acompanhado de refrescos e sobremesa, era a última etapa do encontro dominical, oferecido após o ritual do passe. Mantendo-se sentados, todos recebiam o prato, o talher, o copo; podiam repetir; e aguardavam a sobremesa. A seguir, os participantes retiravam-se, alguns para formarem a fila para receber as bolsas de compras ou bolsas de alimentos; outros para deixarem a instituição. As bolsas eram redistribuídas ao final do encontro dominical, enquanto o salão estava sendo limpo e arrumado, atividade dos trabalhadores da casa, que recebiam ajuda de algumas das usuárias.

A repetitiva seqüência de atividades que compunham o encontro dominical era por vezes questionada pelo usuário, que reconhecia o acesso à bolsa de compras condicionado ao processo de internalização de outra visão de mundo. Outrossim, os agentes institucionais também reconheciam que muitos dos usuários só participavam das palestras pedagógicas para se fazerem dignos do acesso à refeição e à bolsa de compras.

O reconhecimento das motivações diversas e dos investimentos díspares fundamentava a construção de formas de negociação orientadas pelo princípio de reciprocidade que, por sua vez, se pautava em con- 
cessões de ambos os agentes na ritualização comportamental da convivência fraterna positivamente reproduzida.

Os recursos para o preparo das refeições eram obtidos por doações de contribuintes individuais e de gerentes de supermercados. Por vezes, tais recursos ultrapassavam a necessidade do preparo das refeições. Os agentes institucionais preparavam então cestas para que alguns usuários pudessem levar produtos alimentícios para o domicílio. Além disso, alguns dos usuários levavam caixas de plástico para aproveitar as sobras de refeição para familiares que haviam permanecido em casa. Por fim, as sobras podiam ser também redistribuídas aos não-cadastrados ou retardatários, que permaneciam fora do prédio por terem chegado após o fechamento do portão, realizado 10 minutos antes do horário marcado para o início do encontro dominical.

O sistema de distribuição de cestas de alimentos sustentava-se em uma administração racional do descartável e dissolvia as pressões sobre os supermercados e hortifrutis, para onde os que desejavam ser reconhecidos como carentes afluíam, demandando os produtos perecíveis desclassificados para a venda. Doando tais encalhes às instituições filantrópicas para redistribuição a seus usuários, os dirigentes de supermercados e hortifrutis também conquistavam a posição de fornecedores privilegiados para as compras que tais instituições, com recursos dos sócios, passavam a colocar em prática ${ }^{15}$.

Torna-se importante destacar como os usuários, diante deste e de outros projetos institucionais de redistribuição de alimentos, foram expropriados das iniciativas espontâneas em busca do lixo reaproveitável. Embora este controle possa responder aos atos de repulsa decorrentes da observação dos pobres coletando lixo, ele também foi retraduzido em atos de ressocialização ou de incorporação de novos valores e modos de comportamento, todavia, nem sempre incidentes sobre os reais coletores, mas sobre os que têm condições de responder aos critérios de seleção para esta nova forma de redistribuição.

Complementando o sistema de trocas, por vezes eram oferecidos cursos de alfabetização para adultos, conforme programa organizado pela Associação dos Funcionários do Banco do Brasil. Por ocasião das festas natalinas, um almoço de confraternização era realizado em uma escola pública próxima, e cestas de alimentos eram transferidas. A participação neste almoço de confraternização era de tal forma valorizada pelos usuários, que eles, neste período, tendiam a intensificar a aproxi- 
mação com a instituição, visando usufruir de um cardápio organizado segundo a concepção de repasto de festa natalina adotado por segmentos da classe média: maionese, peru, farofa etc. Além disso, as crianças recebiam roupas e calçados novos, brinquedos etc. Eventualmente, segundo a apresentação de receita médica e assiduidade do usuário nos encontros dominicais, ele podia ser contemplado com o atendimento da demanda para tratamento médico.

Os serviços e bens a serem transferidos diversificavam-se e estendiam-se conforme os contextos de maior ou menor resposta a tais transferências no seio da sociedade. Ampliavam-se por ocasião das festas natalinas, de baixa brusca de temperatura, de campanhas de reconhecimento do mal-estar entre os pobres. A dinâmica da expansão de serviços é então valorizada como expressão do sucesso do projeto de intervenção. A relação com os usuários é sugestiva para a criação de serviços; os sócios propõem, assim, formas próprias de participação na divisão social de trabalho e de serviços.

ASEF é uma instituição de reconhecimento público, conforme controle e normas elaboradas por instituições estatais: é dotada de estatuto, inscrições fiscais e autorização municipal para funcionamento. Além dos recursos financeiros já citados que a mantêm, os dirigentes valem-se do serviço de produção e difusão de conhecimentos doutrinários. Contando com um sócio que é reconhecido como dotado da capacidade de psicografar doutrinas, ensinamentos e mensagens elaboradas por espiritos evoluídos, agrega-se à SEF uma editora especializada, que detém o relativo monopólio na produção destes bens culturais (livros, vídeos, áudio e CDs sobre palestras proferidas pelo intermediário mentor).

A instituição, segundo seus dirigentes e no contexto do trabalho de campo, encontrava dificuldades para obter recursos de organizações governamentais, não-governamentais e empresas, dado o preconceito constituído pela hegemonia de outros credos, especialmente certos segmentos de protestantes e católicos. Este preconceito era reinterpretado pelos fiéis como produto da sua postura ética e da autenticidade da objetivação dos princípios religiosos, que impedem que os serviços sejam convertidos à condição de mercadoria. Dessa forma, as acusações eram reelaboradas e transferidas para desqualificação de outros credos.

A desqualificação dos outros credos denuncia a hegemonia que vem sendo conquistada pelos evangélicos, não só na administração das ins- 
tituições públicas, especialmente aquelas voltadas para a assistência social e o reordenamento do comportamento social dos pobres, como também na construção de comportamentos e legitimidades que permeiam a concentração do capital. Muitas das grandes empresas são dirigidas por administradores evangélicos que, por sua vez, privilegiam a inserção de trabalhadores portadores do mesmo credo no mercado de trabalho.

A mesma denúncia tem vindo a público por representantes da Igreja católica. Através de artigos publicados no Jornal do Brasil, Dom Eugênio Sales, em defesa do catolicismo, sistematicamente reivindicava o reconhecimento da precedência da instituição no campo e na articulação com o Estado. Reivindicava, assim, a maior abrangência de recursos materiais e imateriais, em consonância com a complexidade da concepção do fenômeno da pobreza miserável. O acesso a esse espaço de comunicação já é revelador dos sistemas de hierarquia de reconhecimento dos diversos credos.

Como a instituição religiosa espírita não havia sido constituída a partir de uma relação estreita com porta-vozes do Estado, seus dirigentes encontraram dificuldades para obter reconhecimento do projeto de moralização, especialmente no que tange à concorrência com outras instituições destinadas a colocar em prática o sistema de ensino. Além disso, como a profissionalização do magistério permitiu aos professores a reivindicação da autonomia da prática de ensino e da diversidade dos vínculos religiosos, as instituições de ensino, cuja diretoria se encontra afiliada ao credo espiritualista, não têm conseguido se consolidar. Diante dos preconceitos em relação à prática espírita, os dirigentes institucionais os reelaboram como problemas a serem administrados, de modo a conquistar o espaço no campo religioso e a adesão dos fiéis. Abrir as portas a interessados sem demandar fidelidade a credos é de fundamental importância para o processo de construção do engajamento de uma rede mais ampla de adeptos.

\section{O POBRE MERECEDOR DE AJUDA: CONCORRÊNCIA E SOLIDARIEDADE}

As formas de construção das versões sobre a dignidade do pedido constituem material importante para a compreensão das relações sociais que estruturam o campo de mediação, espaço de gestão da convergência de interesses diversos entre beneficiários e estes e seus benfeitores. Os discursos aqui considerados para análise foram construí- 
dos a partir da indignidade do pedido, mas seus autores também levaram em conta a presença do pesquisador, geralmente identificado pela convergência de interesses e pela adesão aos princípios defendidos pelos agentes institucionais. Foram produzidos coletivamente, diante da presença e avaliação de outros usuários. Sustentavam-se na capacidade de o interlocutor construir a defesa para uma acusação $a$ priori atribuída: não ser tão pobre como diz. Por isso, tanto as representações enunciadas pelos benfeitores como os depoimentos dos usuários são acusatórios e reproduzem em parte uma visão consagrada do pobre moralizado. Ao mesmo tempo, tais discursos visam produzir critérios para a exclusão do outro, do concorrente, correspondendo, então, às acusações que sobre os pobres pairam. Em decorrência, tais versões constituem peças paradigmáticas de produção de moralidades, mediante o repertório de acusações anunciadas e o aprendizado da construção do pedido.

Os discursos demonstram os efeitos eficazes das ações de rotulagem. São também expressões das interações informais que se produzem com vistas a construir outras modalidades de pertencimento. Por isso, os carentes devem uma parte de suas características aos atributos da posição aí constituídos, isto é, também em parte sob interdependência com as concepções dos dirigentes das instituições, que, publicamente, explicitam diagnósticos e os tratam seletivamente. Os discursos demonstram ainda os modos de construção do convencimento, ou os efeitos das sobredeterminações dos modos de percepção de especialistas na assistência social. Os acusados, pelo menos quando estão diretamente integrados aos eventos institucionais, deixam-se, no exercício da posição atribuída, contaminar pelas acusações. Da mesma forma, os discursos emitidos também demonstram a importância da participação dos beneficiários em grupos neste campo de concorrência reafirmados, recursos através dos quais eles se credenciam ao exercício de construção do caso digno de atenção e das trocas materiais. Os discursos, então, tornam-se produtos da acirrada concorrência que se estabelece entre os beneficiários.

Procurando compreender as relações menos formalizadas que os usuários estabelecem com os agentes institucionais, os pesquisadores que se dedicaram ao trabalho de campo não só os entrevistavam no período que antecede ao encontro dominical, como ali permaneciam observando e participando dos temas das conversações emergidas no contexto da espera. Recolheram informações sobre critérios de avaliação e 
tentaram compreender os padrões de sociabilidade estabelecidos entre eles. No tempo que antecedia ao encontro, delineava-se a melhor situação de pesquisa, pois que, durante o culto, a fala era monopolizada ou concedida a partir de induções dos agentes que coordenavam o ritual. Após o encerramento, todos os participantes retiravam-se apressadamente para suas casas ou para participar de outras situações de redistribuição de bens aos reconhecidos carentes.

À guisa de demonstração, mas constrita ao número de páginas equivalentes a um artigo, descrevo uma das situações de obtenção de dados por entrevistas abertas e observação:

Certo dia, colocando-me, como sempre, na ordem da fila de espera que os assistentes constituem para a entrada no prédio, aberto exatamente para o encontro dominical, dirigi-me a uma das usuárias para justificar as razões da presença dos pesquisadores. E, logo após, solicitei que me explicasse a importância da instituição para ela. Imediatamente, destacou que freqüentava a instituição há três meses, e que foi uma vizinha que lhe informou sobre tal alternativa. Logo após, sua vizinha, no contexto qualificada como companheira ou colega, chegou e ficou extremamente irritada com ela por ter me concedido este tipo de informação.

Circulava entre os usuários uma norma de não-propagação da oferta dos recursos institucionais e, para fazê-la cumprir, eles atribuíam a interdição aos dirigentes institucionais. Na minha presença, a amiga, colega recém-chegada, confirmou a indicação, mas repreendeu a companheira inconfidente, lembrando que elas fingiam não se conhecer durante o tempo em que se encontravam na instituição. Havia uma orientação entre elas (a grande maioria constituída de mulheres) no sentido de informar que cada uma descobriu a instituição por acaso, quando passava de ônibus e percebeu o aglomerado de usuários. Repreendendo incisivamente a vizinha, advertiu: "A gente avisa para você e você fica espalhando para A, B, C". Justificou-se a acusada inconfidente que todo mundo precisa, e que ela, por espírito de caridade, devia então informar a outras pessoas que também precisam.

Portanto, mesmo que os dirigentes institucionais não controlassem os graus de carência material, esta forma de avaliação presidia o comportamento dos usuários, que criticavam moralmente o uso de tais recursos por quem não considerassem carentes. Não havia explicitação sistemática do que fosse a carência, mas situações, analisadas caso a caso, que acenavam para as dificuldades de assegurar autonomia financeira 
para a sobrevivência: velhice, ausência de esposo produtivo, doenças impeditivas de vinculação ao trabalho. Entretanto, um sistema acusatório pairava sobre todos os usuários, exigindo que cada um dispusesse de discurso legitimador da demanda por ajuda. Cada usuário devia demonstrar perante os outros que de fato se tratava de um carente.

Na seqüência da conversa, a usuária desfilou seu conhecimento sobre o campo institucional de redistribuição de bens para pessoas carentes, demonstrando que tal saber derivava de sua astúcia e capacidade de observação. Sempre que percebia acúmulo de pobres diante de qualquer instituição, procurava se inteirar das condições de funcionamento do sistema de redistribuição. Informou-me então que freqüentava outros centros espíritas, listando-os com seus respectivos endereços. Após a demonstração de saber, tentou relativizar sua inconfidência diante da pesquisadora e procurou controlar minhas intenções, com receio de eu estar ali exatamente objetivando o controle sobre as infidelidades institucionais. Na dúvida, assegurou que esta multiplicidade de inserções é a norma do grupo dos usuários, e que se o controle dos dirigentes caminhasse para uma suposta plenitude, no limite, inviabilizaria a vida institucional. E concluiu: "a punir um, deveria punir todos e fechar as portas da instituição". Reafirmou, então, a solidariedade entre os usuários, cada um informando aos companheiros privilegiados em sua confiança. E para melhor controlar os efeitos das informações prestadas, narrou o seu caso específico, destacando as razões que julgava necessárias e válidas à condição de merecedora da assistência social. Informou que ela não apanhava alimentos só para ela, mas também para as filhas e noras. Acentuou, assim, um dos critérios de controle e de crítica moral, qual seja, ser portador de olho grande, recolher mais do que pode ou deve consumir ou até vender o excedente. Explicou que as noras e filhas eram jovens e que os dirigentes das instituições as excluíam dos benefícios, alegando que elas deviam trabalhar. Ela, idosa, como se classificou (as duas usuárias em foco estavam com 58 e 61 anos), e acompanhada dos netos, apresentava-se na condição de elegível segundo critérios institucionais. Além de recolher os alimentos e estocá-los para ajudar filhas e noras, ela precisava ser previdente, visto que as instituições, de vez em quando, interrompem seu funcionamento. Por vezes ocorre também a diminuição da quantidade de recursos redistribuídos. O acúmulo é, então, providencial para os períodos de escassez relativa ou absoluta. Por fim, sentenciou a máxima que deveria presidir o comportamento de todos os usuários: “Cada um tem que tratar de si e não se importar com a vida dos outros". Desqualificou 
também outros usuários que se dirigiam à instituição com a única finalidade de receber bens materiais, diferente dela, que priorizava a participação religiosa. A obtenção de alimentos, segundo ela, era contingencial. Construía-se, assim, como modelo ideal de beneficiária ou carente.

Não conseguindo sobrepor o dever de guardar segredo à demonstração de seu saber e de seu poder sobre aqueles que dela passam a depender, demonstrou, comparativamente, as formas de atendimento de diversas instituições de redistribuição de bolsas de alimentos e roupas. Destacou o constrangimento imposto pelos dirigentes da SEF de só realizar cadastramento uma vez por ano, o que dificultava o acesso e impunha a necessidade de investimento por longo tempo, até ter assegurado o reconhecimento institucional pelo cadastramento.

Para esclarecer as razões pelas quais percorria outras instituições assistenciais, contou que o marido morrera de câncer há quatro meses, que a pensão estava atrasada, e ela se encontrava sem recursos financeiros. Outrossim, autovalorizou-se pela demonstração que, até o final da idade laborativa, trabalhou em casa de família. Reafirmou, para efeitos de meu convencimento sobre a moralidade de seus argumentos e atos, a dificuldade financeira dos filhos e seu papel positivo na colaboração com a provisão da família extensa. Lembrou, então, que não podia contar com eles. Sustentavam família numerosa e filhos totalmente dependentes. O marido da beneficiária que empresta seu discurso a este texto, conforme sua avaliação, nunca fora exemplar na contribuição financeira para o sustento da casa: era chefe da seção de limpeza, funcionário da Prefeitura, podia contar com a estabilidade no acesso ao salário, mas bagunçava arranjando mulheres na rua. Tanto que, embora vivessem sob o mesmo teto, estavam praticamente separados ${ }^{16}$.

Quando lhe perguntei sobre o trabalho dos filhos, ela não quis especificar, reduzindo a informação à resposta: "Eles trabalham para eles, são pobres, têm muitos filhos e constantemente estão desempregados". Genericamente, explicou que são funcionários de condomínio residencial. Alegou ainda ser ponto de referência para os filhos porque nem sempre conseguem estabilizar-se em uma mesma residência, em face da violência interna aos bairros periféricos. Destacou, como exemplo, a recente mudança de um deles, pai de uma filha moça, que teve que se deslocar de residência por causa da bandidagem.

Alegou ainda, dentre o rol de dificuldades que justificam a freqüência às instituições filantrópicas, o fato de morar em um barraco junto à li- 
nha do trem, razão pela qual a casa estava sempre danificada (paredes rachadas). Definindo o local de habitação como situação de risco, ela nutria expectativas de que fosse intimada a transferir-se de residência, condição a partir da qual esperava auferir concessão pública de habitação sob melhores condições.

Como já destaquei e exemplifico com o relato anterior, as conversas entre a pesquisadora e os beneficiários institucionais eram sempre encerradas bruscamente, tão logo se aproximasse o horário de entrada no interior da instituição. Aberto o portão, todos rapidamente dirigiam-se ao salão destinado a receber os fiéis para o encontro dominical; as mulheres aglomeravam-se de um lado, e os homens, a maior parte moradores de rua, sentavam-se do outro lado. Além da regra institucional de separação dos fiéis por sexo, as mulheres consideravam os homens abusados. Alguns, segundo elas, fingiam que dormiam para cair sobre seus ombros. Na fila, elas comentavam o odor desagradável que deles exalava.

Em síntese, para participar desse campo de redistribuição social, os usuários sentem-se na obrigação de justificar para eles mesmos e para os agentes institucionais a solicitação dos recursos redistribuídos, considerando: a) a demonstração da necessidade material e das dificuldades de acesso a um rendimento adequado; b) o respeito às demandas de todos e a negação da concentração ou do acúmulo de bens; c) os supostos julgamentos morais em face da infidelidade religiosa, ostentando comportamentos correspondentes às diversas afiliações. A participação nas instituições exige deles um constante estado de vigília sobre a concorrência, de modo a não se deixarem passar para trás. Exige ainda atenção sobre os modos de construção das suspeitas e desabonos, temas presentes nos discursos para demonstrar que sobrevivem sob as condições de risco e desqualificantes que sobre eles são projetadas: habitação precária, violência, inclusive sexual, maridos irresponsáveis e alcoólatras, mulheres se responsabilizando sozinhas pela prole etc.

\section{OS TERMOS DE MEDIAÇÃO NA REDISTRIBUIÇÃO CARITATIVA}

A convivência sob vários códigos simbólicos ou expressões de modos de vida nem sempre pode ser facilmente estudada. Uma das condições mais adotadas é a opção por situações de conflito, de deboche, de crítica ou de escolha de adaptações exemplares, que explicitam todo o processo de negociação. Mas se estes são caminhos mais fáceis, nem sempre são tão disponíveis na provisoriedade temporal em que o pesqui- 
sador realiza o trabalho de campo. Além disso, em um processo que se pretende pedagógico, é a explicitação do consentimento que é valorizada e selecionada como exemplar. Levantar uma série de casos sobre usuários também seria operar desnorteadamente pela diversidade. Optei, então, por considerar algumas das questões em jogo no campo constituído para a mediação da convivência dirigida entre indivíduos dotados de posições diferenciadas e, por isso, escolhidas para a integração.

A transmissão do patrimônio cultural de representações constitutivas dos sistemas de crenças cristãos diante da pobreza e da miserabilidade ocorre entre gerações, tal como se pode revelar pelo investimento nas crianças, mas também entre segmentos diversos, mesmo que os indivíduos em questão possam estar dotados de menor plasticidade, tendo em vista os sucessivos processos de socialização. Em relação às crianças, o investimento é geralmente visto como decisivo, em face da pressuposta plasticidade necessária à amplitude do projeto civilizatório.

$\mathrm{O}$ atendimento aos adultos que os dirigentes institucionais preconizam visa, então, propiciar a inculcação de formas de percepção do mundo e de internalização de disposições entre as crianças. O investimento é fundamental à projeção no tempo da proposta educacional. Esta opção consciente encontra formas de legitimação na própria doutrina espírita.

Em conseqüência, o cuidado dos pobres através das crianças (acompanhadas de mães e avós, portanto, mulheres) constitui o investimento considerado mais assegurado para controlar os riscos atribuídos como inerentes a esta posição: combate à criminalidade e à expansão de comportamentos desviantes. Enquanto luta contra a criminalidade, a solidariedade e a fraternidade para com os pobres são deveres de todos, postura e responsabilidade transmitidas geração à geração são um patrimônio da civilização cristã.

O estudo da transmissão de patrimônio imaterial não se adequa à descrição, mas à interpretação. Por isso, tentarei analisar, considerando as práticas diferenciadas dos agentes, alguns princípios e valores que são exaltados para nortear comportamentos comuns e sistemas de interpretações que possam ser comungados ou negociados. Pauto-me, para análise deste item, em interpretações próprias, todavia, construídas a partir de notas de caderno de campo ou de reflexões elaboradas com 
base nos discursos públicos proferidos por evangelizadores nas situações de celebração do encontro dominical.

\section{A Caridade: Encontro Universal da Diferenciada Humanidade}

Os dirigentes da SEF têm um duplo objetivo: prestar assistência aos $c a-$ rentes e orientar a evolução espiritual dos afiliados a este princípio de crença, mediante o exercício da doação supostamente desinteressada. A contribuição prestada aos usuários é condição do exercício de aprendizagem de sentimentos e percepções valorizadas pelo sistema doutrinário. É da troca que aí se estabelece que a instituição operacionalmente realiza os objetivos apregoados ou que os mentores intelectuais do projeto cumprem suas intenções.

A perspectiva de ação assim definida reordena os modos de participação dos agentes e permite a incorporação do projeto de mudança social, a partir do consenso em relação a determinados quereres e motivações. Este consenso mobilizadamente construído se pauta na tentativa de colocação em prática do que é idealizado. O projeto de intervenção, portanto, pressupõe a correlação entre pensar e agir.

As motivações para o agir são contextualizadas e, no momento do trabalho de campo, decorriam, em grande parte, de uma tomada de consciência das contradições sociais, explicitadas de forma mais trágica por apelos politicamente construídos em consonância aos múltiplos significados atribuídos aos termos exclusão e excluído. Por estes termos, os agentes institucionais acenam para um futuro miserável a açambarcar expressivo segmento da população. A exclusão não sendo absoluta desdobra-se em formas de inclusão novamente discriminadas: a violência indiferenciada, a expansão da criminalidade, o crescimento do número de crianças de rua, de população de rua ${ }^{17}$. A dramaticidade inerente aos significados dos termos demonstra, para os agentes desta "cruzada moral" (Goffman, 1970; 1974), a necessidade de controle da periculosidade do pobre e, por conseqüência, a necessidade de implementação, pelos promotores da emancipação, de obras de educação e reabilitação.

O controle dos espontaneísmos de sentimentos caritativos pela canalização ordenada, administrada e concentrada sob os auspícios de uma instituição religiosa, torna socialmente visível e eficaz a mobilização em torno da construção e da gestão de um novo contrato social, idealizado pelos significados atribuídos à solidariedade ${ }^{18}$. Este contrato re- 
define os modos de afiliação de benfeitores e beneficiários. Ao mesmo tempo, expropria consentidamente o valor das iniciativas individuais e redefine as virtudes, reconhecidas se exercitadas no espaço coletivo constituído pelas instituições religiosas. Desse modo, os agentes religiosos reivindicam para si a garantia da probidade dos homens e a inculcação de valores morais. Administrados por esta operação ou, conforme Bourdieu (1989), violência simbólica, os atos de caridade passam a ser governados pelos da generosidade, virtude superior, embora ambos os sentimentos sejam instrumentais a esta demonstração pública ${ }^{19}$.

A articulação entre o pensar e o agir baseia-se na socialização e no direcionamento dos modos de vivenciar determinados sentimentos. Portanto, as emoções evocadas pela troca caritativa não podem estar expostas a espontaneísmos, devendo ser incorporadas pela problematização do senso comum religioso, exercício que constrói a especificidade do sistema de crenças e as razões para a concorrência com os demais, que articulam outras modalidades de correspondência entre idealização e objetivação.

A participação no conjunto de atividades da SEF opera como um laboratório de aprendizagem de sentimentos condizentes com a doutrina espírita. Não há prática desinteressada. Tudo conclama no sentido de tornarem objetivadas as intenções. Tudo conclama no sentido de universalizar o diferente. É o caso do reconhecimento de sentimentos supostamente universais, como a dor, que não poupa nem respeita as hierarquias. Assim sendo, um dos objetivos latentes é relativizar a extrema diferença dos agentes escolhidos para a aproximação, igualando-os mediante certos princípios abstratamente universais, como a humanidade, na prática, ensinada por Cristo. A pobreza material, advertem os evangelizadores, é reflexo da pobreza da alma, do espírito ainda embrutecido, do apartamento da humanidade cristã, que condiciona os homens à fraqueza, à degradação, à desclassificação. Partindo do reconhecimento da diferença das condições de vida materiais, porque também morais, os espíritas investem na construção do homem universal em Cristo ou pela relação com esta divindade.

Esta concepção de pobreza e esta qualificação dos pobres não correspondem às elaboradas pelos usuários, salvo no que eles se pensam vítimas e desprovidos de sorte ou escolhidos para o sofrimento. Por tal motivo, reivindicam o reconhecimento da dependência, da necessidade de ajuda e proteção. Mas a concepção dos usuários, pautada na sorte ou na 
eleição, corresponde à mesma concepção, pouco explicitada coletivamente, dos benfeitores. Este silêncio sobre tal concepção se deve à contradição da crença com os princípios doutrinários a que estão afiliados. A mobilização primeira para a prática caritativa também corresponde à concepção que os doadores foram privilegiados pela sorte e, por isso, devem ajudar os desafortunados.

As interdependências constituídas entre os universos culturais diferenciados podem adquirir requerida longevidade, pela relativização da definição da pobreza e da condição do pobre como temporárias. Este discurso é recorrente entre os voluntários, mas é contraposto pelos usuários, que pensam a pobreza como condições crônicas, intergeracionais, legado de constrangimentos para adoção de outras alternativas, e, assim sendo, suscitam investimentos sistemáticos e contínuos, compromissos duradouros com os quais devem se ocupar para superá-la ${ }^{20}$. Ora, a universalidade atribuída à humanidade suporta a produção do discurso legitimador das práticas destinadas a este mesmo fim: a construção do ser moral. Por isso, a comunicação sistemática quanto à crença neste princípio é necessária porque é percebida de modo diferenciado, tanto pelo modelo idealizado dos missionários, como dos seus beneficiários. Em conseqüência, a doutrina espírita, como tantos outros sistemas de crenças que investem na elaboração de explicações a respeito do pobre e da pobreza, reafirma princípios de interpretação do mundo social disputados na construção da civilização ocidental moderna: o medo dos pobres nela mesma produzidos. A explicação sobre a pobreza é, assim, minimizada, derivada da atribuída aos pobres, incapazes, por carências morais - vícios, pecados, falta de coragem e autoconfiança -, de alcançarem condições dignas de vida, mesmo que sob relativa restrição de recursos materiais. A inserção dos pobres neste mundo social de virtudes pressupõe, desse modo, a aceitação de que ele é também responsável pela sua pobreza.

Se as intenções do projeto de intervenção ou gestão social são objeto de acordos, as formas de sua realização são objeto de criatividade, inventividade, adaptabilidade, porque pressupõem a construção da adesão do beneficiário. As ações dos benfeitores estão também referenciadas às possibilidades de recusa dos beneficiários, especialmente aquelas dissimuladas, que não deixam explicitar o desacordo e a resistência quanto à aceitação do que o outro pensa sobre eles ou do que o outro pensa ser bom ou vantajoso para eles enquanto seus protegidos ou controlados. 
Na prática, os objetivos e intenções são diversos porque expressivos da consciência de alcances menos ambiciosos. O principal objetivo é a construção da autonomia dos pobres pela internalização de valores que explicam a importância do trabalho. Mas pode ser menos enfático e se dirigir a "esclarecer as consciências e consolar os corações"; "ajudar às pessoas a encontrarem seu próprio caminho"; "propiciar que as pessoas descubram seu interior ou alcancem o autoconhecimento, exercício que pressupõe o silêncio mental para auto-reflexão".

A instituição apresenta-se, assim, como forma de realização de um duplo processo de intervenção: sobre os que aderem, buscando reflexões espirituais e exercício de objetivação deste sistema de crenças; e sobre os que, submissos à valorização de tamanha carência material, propiciam as possibilidades desiguais de troca e de definições para existência social. Por isso, o trabalho de assistência não é apenas voluntarista e espontaneísta. Pressupõe a formação, a adesão a um sistema de crenças e de visão de mundo.

O princípio racional-afetivo referenciador deste sistema de crenças que integra os mais ou menos intelectualizados fundamenta-se nos sentidos atribuídos à categoria caridade: dar e doar-se. Por isso, independentemente da diferenciação de saber, todos são unânimes em proclamar: "A caridade é a pedra fundamental. Sem caridade ou fora da caridade, não há salvação". Estes significados não são expressos apenas como princípio, mas também como prática ou como envolvimento e demonstração de amor ao próximo. Por isso, vaticinam: "Não é somente dar as coisas, é ajudar nas dificuldades: dar assistência material, moral e afetiva. A caridade material é um trabalho assistencial e moral". Por isso ainda, consagram: a adesão aos valores associados ao termo caridade referencia uma forma de viver no mundo.

Portanto, a formação espiritual orienta as relações entre os segmentos diferenciados e colabora na constituição social dos sentimentos que reafirmam e diluem a distinção. Contudo, os trabalhadores da casa engajam-se segundo visões de mundo que estão subjacentes ao conforto moral que a transferência de recursos entre desiguais pressupõe. Por isso, os agentes institucionais menos intelectualizados na elaboração de sua fé (ou portadores relativos do direito de difusão dos princípios doutrinários mais consagrados) põem em destaque outras referências. Destacam os efeitos dos investimentos na implantação de determina- 
das normas disciplinares, na construção do comportamento humano mais adequado para realizar uma suposta boa sociedade.

A inserção de usuários e trabalhadores da casa no sistema de trocas e construção de concepções de mundo torna-se ainda viável pelo diálogo em torno dos modos de convivência com o sofrimento, mal-estar que atinge a todos indiferenciadamente. $\mathrm{O}$ exercício de deslocamento simbólico para a posição do outro - ou para um mundo social efetivamente diferenciado, porque se objetiva a partir de sistema de posições caricaturadas - demonstra sua eficácia porque é percebido como instrumento de cura da dor e das perdas.

Uma das trajetórias valorizadas para a demonstração das modalidades de participação dos trabalhadores da casa é reconstituída mediante uma ruptura com modos de percepção anteriores. Ela é quase sempre explicitada diante de grandes momentos de sofrimento, em que a convivência e a sociabilidade, orientadas por este princípio de percepção dos males, demonstraram sua eficácia. Tais concepções de mudança por transposições orientadas por outras referências morais, elaboradas diante de grandes sofrimentos, aplicam-se a todos os participantes da SEF. Por elas, benfeitores e beneficiários se encontram pressupondo a integração a um processo de conversão social ou de afiliação a uma comunidade de crenças e de gestão coletiva de sofrimento. Esta experiência de conversão, acenada para todos, pressupõe a administração do sentimento de sua plausibilidade e a aprendizagem dos quadros de pensamento instituídos na comunidade institucional, indispensáveis para a estruturação da nova realidade. É neste contexto que todos devem se reconhecer como iguais e diferentes, mas confirmar a possibilidade de emergir um novo ser e uma nova identidade. A socialização no exercício destas posições implica, então, a reorganização dos termos de construção dos discursos pela (re)significação dos sentidos. É na convivência com este novo sistema de significados que a realidade subjetiva de benfeitores e beneficiários pode ser pensada em transformação ${ }^{21}$.

Portanto, o estudo da prática filantrópica, associado ao do processo de expansão das organizações não-governamentais e de novas formas de agregação e construção de identidades, põe em relevo outros processos de construção de estilos de vida, valorativos da participação e da responsabilidade sociais. A diversidade de tipos de ações voluntárias é enorme. Este artigo apenas contribui para pensar o caso dos voluntári- 
os religiosos, mas sua amplitude deve ser reconhecida. A prática filantrópica expressa movimentos em curso, de valorização da solidariedade como instrumento político de compensação dos crescentes mecanismos de segmentação social ou de exclusões sociais, como geralmente vêm sendo politicamente reconhecidos ${ }^{22}$.

\section{Os Carentes como Sujeitos da Evangelização}

Os agentes institucionais não elaboram discursos sistematizados sobre os carentes por disporem da convicção de que tais posições são efeitos do descaso no investimento da evolução espiritual. Quando se referem a eles mediante explicitação de pontos de vista que reconhecem a alteridade, exaltam as dificuldades para o relacionamento e para colocação do seu projeto em prática. Assim, eles - forma indefinida com que são construídos pela generalidade - orientam-se pela desconfiança, por não estarem habituados ao merecimento da consideração pessoal. A objetivação do projeto pressupõe, então, a conquista da confiança. Eles desconhecem ou irreconhecem a disciplina necessária à participação no ato religioso, razão pela qual devem ser objeto de investimentos no sentido da aprendizagem de comportamentos adequados. Eles são desprovidos de hábitos de higiene material e mental, motivo pelo qual devem incorporar formas diferentes de percepção orientadoras das concepções de vida material e moral. Eles carecem de usos especiais do corpo, condição a partir da qual devem desenvolver a coordenação motora necessária, associada à concentração mental de que são desprovidos. Aprender a concentrar-se mentalmente torna-se, então, um projeto, um fim e um meio. Complementarmente, a internalização de determinadas concepções de asseio corporal, expressivo da aceitação de princípios morais, enfatiza a idéia-valor da purificação em amplos sentidos.

A mobilização dos carentes, contudo, sustenta-se na distribuição de serviços e bens e no acatamento de regras de inserção institucional. Para a participação no encontro dominical, que abarca recreação, orientação de hábitos saudáveis de vida material e moral e palestras doutrinárias, o interessado deve se cadastrar e se comprometer a não faltar, opção que lhe dará a prerrogativa da participação, mas que o excluirá a partir da terceira ausência. A pressão dos que insistem neste reconhecimento facilita a decisão pela exclusão do faltoso. O processo de cadastramento constitui-se, igualmente, em princípio de imobilização social do beneficiário, porque se sustenta na assiduidade. A alternativa de 
participação na conquista de recurso raro, visto que o cadastramento é realizado uma vez por ano, pressupõe a socialização nas normas institucionais por parte do interessado. Além disso, o cadastrado pode ser convidado a abandonar tal prerrogativa, caso não apresente um comportamento condizente com a participação em atos rituais de vivência religiosa ou em palestras. Por isso, a expectativa é de que aceite um comportamento disciplinado, obedeça a um horário preciso para entrar e para sair, momentos em que o portão da instituição é aberto.

Como há alternativa de incorporação dos não-cadastrados que concorrem com os indisciplinados e não-assíduos, os que desejam manter sua vinculação de cadastrado devem chegar relativamente cedo para assegurar lugar no salão destinado às palestras. Cada um é responsável por este controle, sendo vedada a reserva de lugares para os retardatários. De qualquer forma, apesar de o portão ser fechado em um horário preciso, há alternativa de recebimento de alimentação, caso a demanda dos que estão no interior do recinto permita.

As palestras difundem um sentido muito exato para a evangelização, embora sejam elaboradas tendo em vista a transferência de princípios doutrinários e, por isso, atendam muito mais ao objetivo do disciplinamento do comportamento social do que da conversão. De fato, o controle não se dá no sentido de receber apenas convertidos ao sistema doutrinário. Não importa o sistema de crenças do usuário, ele pode se beneficiar dos serviços, desde que respeite as normas de comportamento social próprias da instituição. No único momento em que a ação dos evangelizadores se faz mais específica, na ministração dos passes, o direito de se retirar do salão é publicamente ou oficialmente anunciado. Esta reserva é adotada por vários participantes, inclusive os mais assíduos. Contudo, pelo consenso entre transmissores e receptores de que é possível melhorar as condições espirituais e, por conseqüência, materiais de vida, pela renovação de energias, o passe é um recurso valorizado pela grande maioria, muitos deles para lá acorrendo em busca deste serviço ou justificando sua ida, não pela carência material, mas pelo bem-estar advindo da participação nesta prática ritual.

O momento de participação no processo de evangelização dos usuários é referenciado por comportamentos mais lúdicos, sendo freqüente a prática dos cânticos, quando são selecionadas canções da música popular brasileira ou da doutrina espírita, portadoras de mensagens que valorizam o enquadramento de formas de percepção do mundo e de si 
mesmo. Tomando uma situação como exemplo, uma canção de conhecimento e aceitação gerais, Se eu quiser falar com Deus, de autoria de Gilberto Gil, é deslocada do repertório da música popular brasileira para operar como um cântico durante as sessões de preces.

As letras das canções constituem substrato para a reflexão sobre princípios orientadores do comportamento. A construção destas novas formas de percepção e enquadramento é marcada por perguntas relativamente dirigidas, sendo as respostas positivas estimuladas pela concessão de prêmios aos enunciadores. Os prêmios são geralmente bens destinados à alimentação - caixas de leite in natura, latas de leite em pó, caixas de chá etc.

Contudo, todos estes recursos de procedimento para internalização de visões de mundo são instrumentais a uma comunhão de sentimentos em que se exprime, da forma mais ritualizada possível, a alegria do encontro entre desiguais, o prazer da doação e o investimento na valorização do que está na situação de desqualificação. E de tal modo este sentimento é perpassado que todos os usuários valorizam a dignidade com que são recebidos, dignidade objetivada nas boas maneiras ou educação e na valorização da apresentação, da quantidade e do gosto do alimento oferecido. Dignidade de tratamento reconhecida pelo fato de se sentirem percebidos como pessoas e não como coisas indesejáveis. Os trabalhadores da casa reconhecem histórias pessoais dos usuários, pegam no colo as crianças enquanto as mães almoçam, demonstram interesse pela evolução de uma doença etc. Além disso, as crianças são acariciadas, e as mães recebem atenção individualizada, demonstrada pelo interesse sobre as condições de vida dos filhos. O reconhecimento da dádiva acentua-se porque os beneficiários sabem que o alimento é adquirido e preparado por concessão dos trabalhadores da casa. Estes, por sua vez, orgulham-se da refeição que distribuem: "almoço substancioso, com fartura, e preparado com muito carinho". O prazer por tal ato de transferência de si ou de reconhecimento desta importante participação social é perpassado pelo ambiente de confraternização.

Neste reconhecimento do encontro entre desiguais talvez se construa a melhor eficácia da ação política junto aos pobres: relativiza o descrédito, o estigma e a marginalidade cultural; e constitui o espaço de reconhecimento de trocas entre benfeitores e beneficiários. Esta situação de encontro possibilita a explicitação de acordos e a relativização dos desacordos quanto aos significados de visões de mundo diversas. Pressu- 
pondo o sistema de diferenças, no entanto, estão abertas as alternativas para a disposição relacional. O contato opera como fato constitutivo do reconhecimento social dos pobres e de redefinição de sua identidade e pertencimento social.

Esta valorização positiva do usuário socialmente desqualificado é também construída pelo reconhecimento de que a instituição abre alternativas para que a população de rua, expropriada da possibilidade de guardar sua privacidade, possa desfrutar de espaços e momentos de auto-reflexão. A reflexão é considerada fundamental na superação de certas dificuldades, desde que sustentadas no entendimento da provação por que passa o corpo e, conseqüentemente, na aceitação do sofrimento com resignação e desprendimento.

\section{Os Carentes e a Dignificação Moral pela Redistribuição}

Definidos genericamente como população carente - pessoas que moram na rua, pessoas que moram na favela, pessoas que moram em cortiços, a instituição, como já destaquei, recebe crianças acompanhadas, tendo destaque a presença de mulheres. Portanto, na divisão familiar do trabalho, às mulheres cabe papel fundamental na coleta de recursos para sobrevivência. Entre os homens, poucos são aqueles dotados de famílias, sendo, por isso, classificados como mendigos ou pessoas que moram na rua. Neste caso, o princípio básico de distinção é a presença ou a ausência de habitação particular.

Esta segmentação é flagrante nas formas de apresentação dos usuários. As crianças, adultos e velhos que dispõem de habitação particular apresentam aspectos mais saudáveis, mais limpos e, dessa forma, são avaliados como melhor orientados. O uso dos recursos institucionais é incorporado como parte do projeto de melhoria das condições de vida, por vezes de uma família extensa, sendo assim também beneficiários aqueles que permaneceram em casa, por estarem impedidos de se locomover ou por não se sentirem autorizados entre eles mesmos a percorrer instituições como pedintes, caso específico de homens e mulheres que trabalham ou estão em idade laborativa.

O segmento identificado como população de rua, na sua imensa maioria constituído por homens, não dispõe do mesmo padrão de higiene dos demais. Comumente estão vestidos com roupas sujas, demonstrando a dificuldade de manter os mesmos hábitos de apresentação. Além disso, têm sempre semblante cabisbaixo, aspecto menos saudável, especi- 
almente nos períodos mais frios, e são bastante inquietos durante o encontro dominical. Dormem a maior parte do tempo, saem da sala, irritam-se e se retiram tão logo o almoço é servido.

As mulheres comparecem relativamente arrumadas, demonstrando zelo e cuidado com a aparência, seja para se diferenciarem das demais, seja para melhor se apresentarem diante dos agentes institucionais, isto é, pobres, mas orientadas (potencialmente portadoras de condições para incorporar orientações e desdobramentos da situação, por esse ponto de vista, de carência provisória).

O cadastro que a diretoria da instituição organiza não tem por objetivo identificar a origem social do usuário. São solicitados ao demandante de inscrição: o nome, a idade e a data em que começou a freqüentar a instituição, sendo, a partir deste ato, controlada a assiduidade aos encontros dominicais. Este registro visa adequar o número de presentes ao espaço físico e controlar a previsão dos recursos a serem redistribuídos, bem como as condições de reprodução da instituição. O princípio geral orientador é: antigüidade é posto. A assiduidade, contudo, opera no sentido de facilitar o trabalho de reenquadramento, pela incorporação de novos esquemas de percepção de si e do mundo social. A liberalidade em relação à freqüência impediria a adesão, o disciplinamento do comportamento dos pobres que querem ser assim reconhecidos e, quem sabe, a conversão.

Algumas situações são eliminadas do atendimento: menores de rua e pessoas visivelmente alcoolizadas ou drogadas. Há um controle na porta, no sentido de impedir a entrada de pessoas sob tais condições. E, durante as palestras, são dados avisos sobre esta interdição. São organizadas campanhas no sentido de eliminar os que aparecem com odor de uso recente de bebida alcoólica. Por vezes, este controle é ritualmente caricaturado pela direção. O combate aos vícios mobiliza os associados em uma grande campanha moral de redenção dos homens.

Independentemente de os dirigentes institucionais e evangelizadores não questionarem as causas da pobreza e avaliarem os bons ou maus pobres pela assiduidade ao vínculo institucional, os usuários sentem necessidades de se explicar e justificar a participação nos atos de redistribuição de comida. Torna-se evidente que a busca da alimentação constitui o primeiro motivo da presença dos usuários. Eles estão a todo tempo controlando a concorrência; sempre criando formas de se anteciparem na obtenção dos recursos. As equipes de evangelizadores devem 
acompanhar este movimento e minimizar a ansiedade expressa na desatenção.

Um segundo motivo explica a significativa presença de velhos e mulheres adultas: alternativa para o passeio aos domingos. O encontro com os colegas, o bate-papo, o deslocamento e a orientação evangélica são definidos como recursos de lazer propiciadores de momentos de sociabilidade.

A diversidade de sentidos atribuídos pelos usuários à participação é demonstrativa do exercício sistemático de construção e busca de outras alternativas para o enfrentamento das precárias condições de reprodução socioeconômica. Para participar desse campo institucional, é preciso conhecer o circuito de redistribuição, critérios, oscilações, calendários etc. Mas a explicitação deste saber desqualifica o usuário, redefinido como não-carente ou profissional da dependência caritativa. Lidar com esta contradição exige o aprendizado da capacidade de se explicar e de apresentar imagens positivas sobre si mesmo.

As explicações dadas espontaneamente pelos usuários para se definirem como merecedores dos recursos ofertados são de fundamental importância para entender as concepções de pobreza, mas principalmente de carência, entre eles. Elas são publicamente produzidas para os próprios usuários, mas respondem contrastivamente aos significados negativos construídos por outros segmentos sobre eles. Não podendo se desvencilhar dos significados atribuídos às posições de carente ou necessitado como princípio organizador das práticas de redistribuição, eles investem na produção de novos significados e modos de dignificação.

Propiciando o encontro autônomo entre eles, durante o período em que aguardam a entrada na instituição, os benfeitores investem indiretamente na ruptura do isolamento social e cultural a que os usuários se encontram constrangidos. A calçada da rua diante do prédio aparece como um espaço público para elaboração coletiva de representações e visões positivas sobre a indignidade da dependência. Daí a necessidade de participação coletiva na definição do caso pessoal, modo de construção de uma narrativa eficaz na demonstração do drama individual, que explicita a dificuldade de cada um para viver como pobre. Estes momentos constituem espaços de explicitação pública da dignidade e de elaboração e confirmação de princípios de moral que referen- 
ciam seus comportamentos e os comportamentos que atribuem aos benfeitores ${ }^{23}$.

Com certo tempo de freqüência, todos conhecem versões sobre histórias de vida de uns e de outros. A circulação de informações tende a se dar segmentadamente entre os usuários que possuem residência ou família e entre os que são reconhecidos como população de rua. Os pedintes que possuem habitação particular se justificam diante da convivência e da aproximação das condições de sobrevivência da população de rua. De qualquer forma, alegam que os dirigentes institucionais mantêm a disciplina, não havendo abusos. Os homens assim identificados não se cadastram, aguardando a vaga após a entrada dos que asseguraram, sob cumplicidade, este direito. Para a população de rua, o cadastramento opera no sentido de restringir as chances de incorporação de múltiplas alternativas de ajuda. Os que assim se identificam recusam-se ao cadastramento porque, imediatamente, seriam eliminados pela pouca assiduidade. Sua aparência, por si só, impõe o dever da concessão da comida, motivo fundamental da presença deles na instituição.

Os casos relatados são recorrentes em termos de construção de temática justificadora da participação na redistribuição caritativa. As concepções de pobreza e carência aí veiculadas constituem um patrimônio cultural dos usuários, operando na individualização contraposta à massificação ou ao anonimato desabonador, contido na desclassificação geral atribuída à miserabilidade ou à carência. Operam também na construção desta posição, reconhecida pela falta, as acusações de responsabilidade individual e resistência ao engajamento na sua própria reabilitação. A estes atributos negativos, eles contrapõem a vinculação ao trabalho; o testemunho do patrão quanto ao reconhecimento de sua responsabilidade de trabalhador; a solidariedade familiar e vicinal; o saber inerente à capacidade de concorrer entre eles mesmos e de conhecer os modos de funcionamento do campo institucional; isto é, correspondente à habilidade de se integrar, por reconhecimento oficial ou cadastramento, ao se impor por diversas formas de pressão.

Os casos expressam, assim, o próprio mundo do usuário, real ou imaginado, para si mesmo ou para os que, pela alteridade de condição, convivem com eles nesse campo social. Explicitam as motivações para a integração à instituição, mesmo que representadas pela adesão momentânea ao credo proposto e correspondentes às intenções dos dirigentes 
institucionais, por conseguinte, nem sempre à fome imediata. É o que demonstra o caso a seguir apresentado:

Dona S., 64 anos, avó e responsável por dois netos, de 12 e 14 anos, relata que sua filha, a mãe dos referidos netos, morreu há seis anos por causa de envolvimento com comércio de droga. Ela passou então a tomar conta dos dois meninos. O de 14 anos tem comportamento por ela considerado ótimo, mas o de 12 anos não se deixa controlar. "Faz o que quer, não vai para a escola, pega coisas dos outros". A avó não consegue corrigi-lo e quer interná-lo. É recorrentemente aconselhada a não tomar esta atitude, por correr o risco de piorar a situação de marginalidade do neto. Contudo, alega, a situação de risco já está dada. O neto já apresenta um comportamento desviante. Na companhia dela, adverte, "ele vai virar bandido", porque não lhe obedece. Procurou uma vereadora para ver se conseguia colocar o menino na Fundação da Infância e Adolescência - FIA. Também procurou apoio no Centro Juvenil de Orientação e Pesquisa -CEJOP, com a intervenção da pedagoga, psicóloga e fisioterapeuta, porque ele é gago. Diz ser ele traumatizado porque os pais brigavam muito. A mãe jogava querosene e água quente no marido, e o menino ficava muito nervoso. Tentou obter apoio para tal problema na SEF. Esta era a razão pela qual solicitava recursos: auxílio complementar e institucional para educar o neto. Os agentes institucionais não se ocupavam deste tipo de demanda pela população carente. Diante da restrição, Dona S. aceitou o que lhe foi oferecido: além de almoçar e levar refeição dominical para os dois netos, conseguia ali viver momentos de paz e de súplica aos poderes espirituais para que a ajudassem a obter uma solução para os problemas que a atormentavam.

O empenho da avó no sentido de assistir e orientar os netos é por si só valorizado e digno de apoio, dados os limites físicos e financeiros para reatualizar o papel de mãe e o empenho em não estimular a vida independente, na rua, de dois adolescentes. Esta responsabilidade assumida pelas avós constitui situação exemplar para o merecimento da ajuda e para o pedido de colaboração. Portanto, o critério de carência também é bastante relativo entre os usuários, embora algumas situações sejam emblemáticas: pessoas incapacitadas de trabalhar e responsáveis pela assistência a crianças, especialmente se abandonadas pelos pais. Estes critérios são produzidos e reproduzidos para conferirem dignidade aos pedintes e valorizarem as posições de uns vis-à-vis os outros. 
Todos os usuários, no entanto, reconheciam que não eram controlados ou submetidos a concursos de pobreza para freqüentarem a SEF. Recorrentemente, eles afirmavam: "Vem branco e bem vestido pegar comida, eles não fazem o controle. Dão até a quem não precisa". Alguns, contudo, orgulhavam-se de sua condição de usuário preferencial, status obtido por assiduidade ou adesão.

\section{CONSIDERAÇÕES FINAIS: 0 HUMANISMO SALVADOR E AS FRONTEIRAS DE COGNIÇÃOO}

Na cultura cristã, condena-se o descaso com a solidão dos pobres ou o seu abandono. Os cristãos devem assim irmanar-se pela demonstração de que o consolo constitui meio eficaz para a construção de uma sociedade mais fraterna, mesmo que sustentada em tamanha desigualdade. Menos que converter os pobres em espíritas, os dirigentes da SEF põem em ato a construção de uma sociedade menos conflituosa. E, assim, redimensionam o seu projeto de participação e de percepção de utilidade social, motivados pelo desejo de ultrapassarem o absolutismo dos sentimentos individualistas, desqualificados como egoístas.

A despeito de as categorias classificatórias que definem a posição social dos usuários serem desabonadoras, só nesta condição eles podem usufruir da circulação de recursos. É da aceitação do julgamento da carência do demandante que o usuário institucional pode colaborar para emergir o beneficiário e o benfeitor. O protetor, contudo, deve, a partir deste reconhecimento, corresponder em termos das trocas esperadas.

Para que os interesses de benfeitores e beneficiários sejam relativamente atendidos e ao mesmo tempo reconhecidos como diferenciados, algumas expectativas devem ser comuns e algum tipo de atendimento deve torná-las realidade. Esses pressupostos, referenciadores de comportamentos e práticas, configuram a constituição de campos de mediação inerentes às trocas redistributivas sob o ideário da filantropia.

Por essas experiências partilhadas, os agentes que integram os campos de mediação criam um acervo coletivo de conhecimentos e de controle de recursos. Os conhecimentos aí institucionalizados não podem ser adquiridos fora deste próprio campo de mediação, embora outras disposições possam facilitar a participação ou negociação. Eles propiciam o enquadramento e a reprodução de benfeitores e beneficiários; a definição coletiva de formas de mobilização e de produção de adesões; e também dão continuidades singulares a valores e universos simbóli- 
cos que explicam aquelas posições no mundo e as biografias de cada um. Têm, assim, caráter ordenador.

Participar de um universo diferenciado mas desejado é partilhar de uma ressocialização ou engajar-se na busca de uma ressignificação. A convivência em espaços interculturais pressupõe uma vontade de abertura de universo, de engajamento em domínios de ação, reflexão e inovações, colocando em questão os cruzamentos destes vários pertencimentos culturais.

O uso metodológico do termo mediação social, para efeitos deste artigo, deve então ser entendido pela aceitação de seu sentido polissêmico, pressupondo: o que se coloca entre dois universos culturais visando ao diálogo, ampliando ou reduzindo o conflito; a abertura para o conhecimento do outro; a negociação fundada no a priori da abertura para o pensar e o agir diferentes; os investimentos no sentido da produção de mudanças. Os investimentos correspondentes, no caso em pauta, acenam com as possibilidades de participação e reprodução de legados culturais de crenças, de solidariedade, de hierarquia e diferenciação, compreendidos se levados em conta nesta participação contextual. Os termos que aí são tão caros integram a herança cultural e revelam modelos de orientação e ressocialização, confirmando que a transmissão não é reposição, mas transformação. Portanto, se os significados atribuídos à caridade, um desses importantes termos, instauram uma relação de troca entre desiguais, eles também propiciam a constituição de um espaço público para cada agente (com ela comprometido) falar de si, ver-se e rever-se na sociedade.

Investindo na inserção nesses espaços de fronteiras de universos culturais distintos, os usuários projetam-se em outras redes e aí se personalizam, abrindo espaços para eles próprios se constituírem em outros mediadores de novos adeptos e para ampliarem as formas de afiliação social. Por estas afiliações, eles ainda criam a camaradagem e o reforço simbólico para a apropriação dignificada do espaço público.

Os recursos materiais, os alimentos, mesmo que necessários, são na verdade instrumentais à participação em mundos sociais que os tomam como trunfos valorizados. Para que os recursos materiais sejam assim secundarizados, os usuários devem investir na reversibilidade de modos de representação de si que sejam pouco abonadores. Fazendo do seu caso uma exceção, os usuários dão provas de que o dito e o previsto pelo benfeitor é seu atributo pessoal. Assim se diferenciam 
dos outros que, na mesma posição, são desqualificados. Relativizando a perspectiva tipificadora, homogeneizadora e desabonadora que os benfeitores lhes impõem, os beneficiários também reafirmam a desqualificação moral dos pobres segundo a lógica do "salve-se quem puder".

(Recebido para publicação em outubro de 2006) (Versão definitiva em março de 2007)

\section{NOTAS}

1. O termo foi politicamente exaltado para pôr em destaque o reconhecimento de que as desigualdades sociais não são temporárias, mas reproduzem ampliadamente personagens residuais ou desnecessários economicamente. Vem sendo consagrado nos textos acadêmicos, especialmente aqueles que reivindicam um caráter de combate e denúncia política da situação de miserabilidade de grande massa da população brasileira. Ver Nascimento (1995:25).

2. A revitalização dos investimentos filantrópicos e caritativos, tanto por parte das instituições privadas como públicas, foi estudada por Neves (1994; 2002a; 2002b; 2003a e 2006), mas também Landim (1995:5-6 e Novaes, 1995:7-15).

3. Sobre a trajetória dos significados atribuídos ao termo pobre, durante os séculos XVI e XX, ver Sassier (1990).

4. O processo de constituição do campo institucional da filantropia na cidade de Niterói (RJ) foi por mim analisado em Neves (2003b).

5. A respeito dessa forma de associação entre cidadania e democracia como instrumento da ação política estatal, ver Ribeiro e Santos Júnior (1996:23-27).

6. Segundo Ferreira (1975), caridade é o sentimento que nos leva a poupar quem deveríamos ou poderíamos castigar, punir; complacência. Tais significados são sugestivos para a compreensão da prática caritativa. Se há consenso na distinção entre caridade - doação para minimizar sofrimento imediato - e filantropia - movimento pedagógico destinado a educar, reintegrar, converter e homogeneizar a humanidade-, na prática estas distinções nem sempre se tornam nítidas. O sentimento caritativo é controlado institucionalmente para fins reordenadores do comportamento do assistido.

7. Venho, por sistemático processo de reflexão e análise empírica, dedicando-me à sistematização de algumas noções e princípios metodológicos por mim considerados mais atinentes ao estudo da mediação cultural e social. Para elaborar tais reflexões, tenho mantido diálogo e procurado inspiração em autores como: Berger e Luckmann (1973); Berreman (1975); Bourdieu (1981); Crespi (1983); D’Incao e Roy (1995); Mauss (1974); Mead e Métraux (1953); Moore Jr. (1987); Weber (1977); Wolf (1971). 


\section{Delma Pessanha Neves}

8. Este artigo constitui um dos subprodutos do projeto integrado de pesquisa Transmissão de Patrimônios Culturais sob Exclusão Social, subprojeto O Campo Institucional da Filantropia, contemplado pelo Conselho Nacional de Desenvolvimento Científico e Tecnológico-CNPq com bolsas de iniciação científica, de apoio técnico e de produtividade, entre março de 1995 e fevereiro de 1999. Participaram do levantamento de dados para a pesquisa nesta instituição os seguintes alunos do curso de ciências sociais da Universidade Federal Fluminense - UFF: Andréa Carvalho Martins Ribeiro, Bárbara e Silva Gregório, Dilma da Silva e Maria Marcia Buss de Souza. O trabalho de campo do projeto integrado estendeu-se de julho de 1995 a junho de 1998 e, na SEF, entre outubro de 1997 e março de 1998.

9. Situação semelhante foi analisada, em Paris, por Fonseca (1986), em um centro de acolhimento de pessoas sem domicílio fixo, categoria englobante dos pobres que reivindicam institucionalmente dependência e ajuda.

10. Fonseca (1986) ressalta os desencontros de objetivos práticos entre os voluntários e os clientes reconhecidos pela ausência de habitação e trabalho. As demandas apresentadas por estes têm poucas respostas porque as instituições se organizam segundo o ideário dos voluntários: reeducar os reeducáveis.

11. Em "Matricentralidade, Indigência e Enraizamento Familiar" (Neves, 2002b) e "As Idosas Provedoras e o Enraizamento Familiar" (Neves, 2006), dedico-me a estudar os efeitos da concorrência entre os usuários, tanto para definir os privilegiados como para reafirmar as intenções proselitistas dos benfeitores voluntários.

12. A redistribuição de cestas básicas evidencia o quanto os considerados carentes são desprovidos do direito de explicitação pública de seus problemas e reivindicações. Atendidos como necessitados, tanto os titulares dos programas de Estado encarregados da redistribuição desses recursos, como os das instituições filantrópicas entram em acordo sobre os alimentos fundamentais que devem ser transferidos, não se importando, inclusive, com os hábitos alimentares regionais. Paralelamente a esta redistribuição sob a forma de dinheiro, tem crescido o mercado de venda de produtos alimentícios. Nas pequenas e médias cidades, era comum ouvir de vendedores de hortifrutis ambulantes, através do alto-falante, o anúncio de que aceitavam o pagamento por tais formas de representação de moeda. Essa ampla incorporação tem motivado a criação de meios de controle, todavia ressignificados por usuários e comerciantes, acordo pelo qual o cartão magnético representa crédito antecipado.

13. Esta questão foi por mim abordada em outros textos (Neves, 2002b; 2006). Ver também Fonseca (1995); Woortmann (1987). E ainda Delgado e Cardoso Júnior (1999; 2000), para considerar o papel dos aposentados no meio rural.

14. Telles (1996:38), analisando as condições perversas decorrentes da exclusão de parte da população dos direitos sociais decorrentes da vinculação trabalhista, destaca: "A justiça sempre foi confundida com ação tutelar do Estado, em que os direitos, quando existentes, não são formulados por referência a uma noção de igualdade, mas numa lógica que cria segmentações que impedem a sua universalização, seja por conta do critério tutelar que define aqueles que estão credenciados, pela sua própria pobreza, aos serviços assistenciais do Estado [...], em que o acesso à previdência social vira privilégio daqueles que conseguem vencer os azares do mercado de trabalho e se credenciar perante a sociedade (e o capital) como trabalhador produtivo". 
15. Essa era uma prática comum entre dirigentes de casas de comércio, com exceção apenas de alguns hipermercados, em que administradores se apropriavam dos encalhes dos alimentos perecíveis para autoconsumo produtivo intermediário (fertilização de hortas e criação de porcos).

16. A desqualificação das formas de desempenho de papéis atribuídos aos homens - pai e marido, principalmente - é parte da temática que justifica a redistribuição caritativa e o papel privilegiado da mulher neste campo. Esta questão foi por mim analisada em outros textos (ver Neves, 2002a; 2006).

17. Sobre as condições de vida desse segmento da população reconhecido como habitante de rua, em complemento às análises sobre o sistema de posições que instauram a coexistência de posições diferenciadas, ver Neves (1994; 2004).

18. Para esta análise, beneficiei-me da leitura dos textos de Jambet (1993); Pappas (1993); e Quéré (1993).

19. Decorrem desta reivindicação as acusações dos não-crentes sobre a exibição dos atos de doação como formas de expressão do egoísmo e da vaidade e a construção da legitimidade da doação discreta e silenciosa.

20. As concepções que orientam os usuários, construídas segundo sistemas de significações específicas, serão analisadas posteriormente.

21. Para esta análise, contei com a contribuição do estudo do processo de conversão elaborado por Berger e Luckmann (1973:69-172).

22. Sobre este tema, valho-me de contraposições com o texto de Lyet (1997).

23. Para uma análise sobre a dinâmica das imagens de si produzidas sob reciprocidade e cujos princípios se assemelham aos aqui explicitados, ver Fonseca (1986).

\section{REFERÊNCIAS BIBLIOGRÁFICAS}

BERGER, Peter I. e LUCKMANN, Thomas. (1973), A Construção Social da Realidade. Petrópolis, Vozes.

BERREMAN, Gerald. (1975), “Etnografia e Controle de Impressões em uma Aldeia do Himalaia", in A. Zaluar (org.), Desvendando Máscaras Sociais. Rio de Janeiro, Francisco Alves, pp. 123-174.

BOURDIEU, Pierre. (1981), “La Représentation Politique, Éléments pour une Théorie du Champ Politique". Actes de la Recherche en Sciences Sociales, no 36-37, pp. 3-24.

(1989), “A Identidade e a Representação. Elementos para uma Reflexão Crítica sobre a Idéia de Região", in O Poder Simbólico. Lisboa, Difel, pp.107-132.

CRESPI, Franco. (1983), Médiation Symbolique et Societé. Paris, Librairie des Meridiens.

DELGADO, Guilherme e CARDOSO JÚNIOR, José Celso. (1999), “O Idoso e a Previdência Rural no Brasil: A Experiência Recente da Universalização?". Como Vai? População Brasileira, ano IV, no 2, pp. 3-14. Brasília, IPEA. 


\section{Delma Pessanha Neves}

(2000), A Universalização de Direitos Sociais no Brasil: A Previdência Rural nos Anos 90. Brasília, IPEA.

D’INCAO, Maria da Conceição e ROY, Gérard. (1995), Nós, Cidadãos. Aprendendo e Ensinando Democracia. Rio de Janeiro, Paz e Terra.

FERREIRA, Aurélio Buarque de Holanda. (1975), Novo Dicionário da Língua Portuguesa, (1a ed.). Rio de Janeiro, Nova Fronteira.

FONSECA, Claudia L. W. (1986), “Clochards et Dames de Charité. Une Étude de Cas Parisien". Ethnologie Française, vol. 16, no 4, pp. 391-400.

(1995), Caminhos da Adoção. São Paulo, Cortez.

GOFFMAN, Erving. (1970), Estigma. Buenos Aires, Amorrortu Editores.

(1974), Manicômios, Prisões e Conventos. São Paulo, Editora Perspectiva.

JACOBI, Pedro. (1995), “Ação da Cidadania, Contra a Fome, a Miséria e pela Vida: Um Registro Necessário". Proposta, ano 23, no 23, pp 27-33.

JAMBET, Christian. (1993), L'Epiphanie de la Miséricorde", in O. Gaudon (org.), La Charité. L'Amour au Risque de sa Perversion. Paris, Editions Autrement (Série Morales no 11), 45-65.

LANDIM, Leilah. (1995), "Apresentação", in R. Novaes (org.), Pobreza e Trabalho Voluntário. Estudos sobre a Ação Social Católica no Rio de Janeiro. Rio de Janeiro, ISER, pp. 5-6.

LYET, Philippe. (1997), L'Organisation du Bénévolat Caritatif. Paris, L'Harmattan.

MAUSS, Marcel. (1974), "Ensaio sobre a Dádiva”. Sociologia e Antropologia. São Paulo, EPU.

MEAD, Margaret e MÉTRAUX, Rhoda (eds.). (1953), The Study of Culture at a Distance. Chicago, The University of Chicago Press.

MOORE JR., Barrington. (1987), Injustiça - As Bases Sociais da Obediência e da Revolta. São Paulo, Brasiliense.

NASCIMENTO, Elimar Pinheiro. (1995), “Modernidade Ética: Um Desafio para Vencer a Lógica Perversa da Nova Exclusão". Proposta, ano 23, no 65, pp. 24-28.

NEVES, Delma Pessanha. (1994), "La Misère en Spectacle". Cahiers du Brésil Contemporain, no 25/26, pp. 61-80.

(2002a), "Apresentação. A Gestão da Precária Inserção Geracional". Cadernos ICHF, no 78, pp. 7-18.

(2002b), "Matricentralidade, Indigência e Enraizamento Familiar". Cadernos CERU, série 2, no 13, pp. 211-230.

. (2003a), “O Legado da Pobreza e a Inserção Geracional”. Ilha - Revista de Antropologia, vol. 5, no 1, pp. 65-89.

. (2003b), "Voluntariado Filantrópico: Humanismo Salvador e Gestão Social”. Revista de Ciências Sociais, vol. 34, pp. 31-48.

(2004), “Les 'Habitants de Rue' à Rio de Janeiro (Brésil): La Gestion des Intolérances". Espace et Société, vol. 116, pp. 71-92. 
(2006), “As Idosas Provedoras e o Enraizamento Familiar", in C. Fonseca e J. Brites (orgs.), Etnografias da Participação. Santa Cruz do Sul, Edunisc, pp. 359-379.

NOVAES, Regina C. Reyes. (1995), "Introdução", in R. Novaes (org.), Pobreza e Trabalho Voluntário. Estudos sobre a Ação Social Católica no Rio de Janeiro. Rio de Janeiro, ISER, pp. 7-15.

PAPPAS, John. (1993), "Le XVIIIe Siècle, de la Charité à la Fraternité", in O. Gaudon (org.), La Charité. L'Amour au Risque de sa Perversion. Paris, Editions Autrement (Série Morales no 11), pp. 66-86.

QUÉRÉ, France. (1993), “Un Mot qui Prend Feu”, in O. Gaudon (org.), La Charité. L'Amour au Risque de sa Perversion. Paris, Editions Autrement (Série Morales no 11), pp. 37-44.

RIBEIRO, Luiz César de Queiroz e SANTOS JÚNIOR, Orlando Alves. (1996), “Cidadania e Democracia: OSentido das Eleições Municipais". Proposta, ano 24, no69, pp. 23-27.

SASSIER, Philippe. (1990), Du Bon Usage des Pauvres. Historie d'un Thème Politique XVI-XXe Siècle. Paris, Fayard.

TELLES, Vera de Silva. (1996), "A Pobreza como Condição de Vida". São Paulo em Perspectiva, série 10, no 4, pp. 85-119.

WEBER, Max. (1977), “Las Comunidades Políticas", in Economía y Sociedad II. México, Fondo de Cultura Económica, pp. 661-694.

WOLF, Eric. (1971), "Aspects of Group Relations in a Complex Society: Mexico", in T. Shanin (ed.), Peasant and Peasants Societies. London, Penguin, pp. 50-67.

WOORTMANN, Klaas. (1987), A Família das Mulheres. Rio de Janeiro, Tempo Brasileiro/CNPq. 


\section{ABSTRACT \\ Poverty and Saving Humanism: Underlying Mediations}

Considering the relatively recent political recognition of the extreme rates of socioeconomic inequalities and massive states of absolute and relative hunger in Brazilian society, alongside the expanded investments in social assistance programs (both by the state and private philanthropy), this article analyzes the conditions for objectively defining a field of intervention-mediation linked by the belief in a saving humanism. The development of this field values forms of mediation between different cognitive universes, corresponding to the worldviews of benefactors and beneficiaries, expressed by the collective construction of terms of communication that redefine interactive positions between Spiritists and the needy. Instrumentally, the field thus values the analysis of practical investments in the constitutive versions of the case that deserves being characterized by material and spiritual need.

Key words: poverty; religion; Spiritism; social mediation; philanthropy

\section{RÉSUMÉ \\ Pauvreté et Humanisme Sauveur: Médiations Sous-Jacentes}

Compte tenu de la reconnaissance politique relativement récente d'indices très élevés d'inégalités socioéconomiques et de situations de famine massive (absolue ou relative) cumulées dans la société brésilienne et, parallèlement, de l'expansion des investissements en programmes d'assistance sociale (proposés par l'État ou par des organisations humanitaires), on examine, dans cet article, les conditions d'objectivation d'un champ d'intervention-médiation, formé autour de la croyance dans l'humanisme sauveur. C'est dans la formation de ce champ que prennent de la valeur les formes de médiation qui relient des univers de cognition différents et correspondent à des façons de voir un monde de bienfaiteurs et d'assistés, exprimées par la construction collective de termes de communication redéfinissant des positions interactives entre spirites et démunis. Sous l'aspect instrumental, on souligne l'analyse des investissements pratiques et des versions constituantes du cas digne d'être caractérisé comme manque matériel et spirituel.

Mots-clé: pauvreté; religion; spiritisme; médiation sociale; organisations humanitaires 